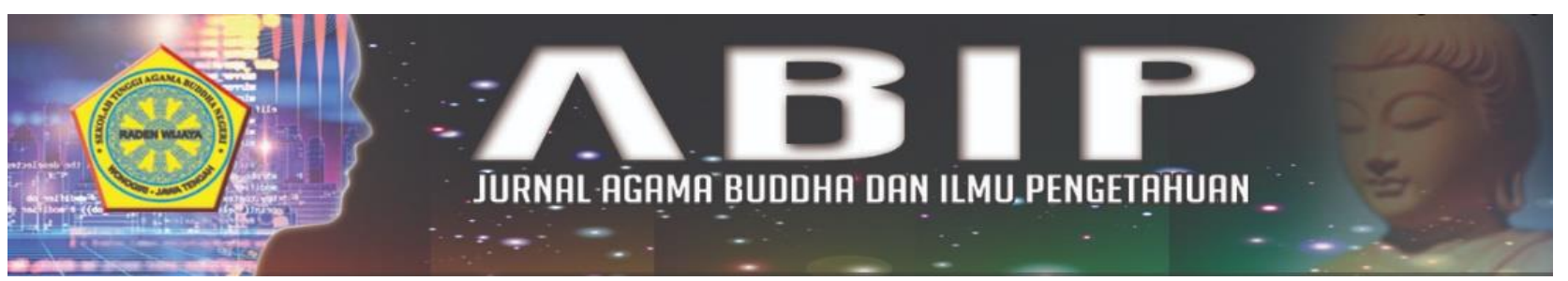

\title{
TINJAUAN FILSAFAT MORAL IMMANUEL KANT TERHADAP PERZINAHAN DALAM PANCASILA BUDDHIS
}

\author{
Oleh: \\ Niken Wardani ${ }^{1}$, Septiana Dwiputri Maharani \\ STABN Raden Wijaya, Universitas Gadjah Mada \\ nikenwardani@ymail.com, septiana.dm@ugm.ac.id
}

\begin{abstract}
Abstrak
Perzinahan dipandang dari aspek religious merupakan perbuatan yang melanggar sila ke-3 dari Pancasila Buddhis yaitu: "Aku bertekad untuk melatih diri menghindari perbuatan perzinahan". Syarat suatu perbuatan disebut sebagai perzinahan adalah: 1) ada objek pelanggaran (perbuatannya); 2) si pelanggar (pelaku); 3) sarana fisik yang siap sebagai kondisi untuk pemuasan nafsu itu (pasangan dalam melakukan perbuatan itu); dan 4) tindakan itu) terpenuhi atau terlaksana. Perbuatan perzinahan disebabkan oleh adanya keterikatan pada objek (lobha) dan kebodohan batin (moha), dan dipengaruhi oleh bentuk pikiran buruk (Akusala-cetasika) yaitu Ahirika (tidak malu berbuat jahat), dan Anottappa (tidak takut akan akibat berbuat jahat). Sehingga akibat dari perbuatan perzinaahn adalah memiliki musuh, tidak disukai semua orang, adanya rasa takut, adanya kecenderungan untuk jenis kelamin perempuan atau jenis kelamin netral pada kehidupan berikutnya. Dan secara sebagian besar perbuatan perzinahan dapat mendorong seseorang terlahir di alam setan (Peta) dan raksana (Asurakaya) apabila dengan kekuatan Lobha yang memimpin, dan terlahir di alam binatang (Tiracchanayoni) dengan kekuatan Moha yang mendominasi. Capaian filsafat moral Immanuel Kant, bahwa perbuatan perzinahan adalah perbuatan yang tidak bermoral karena perbuatan itu tidak membuat manusia menjadi baik tetapi sebaliknya membuat hidup manusia menjadi tidak baik. Sehingga hal itu harus diperangi dengan menjalankan aturan moralitas yang apriori atau wajib dilaksankan supaya kehidupan manusia menjadi baik. Pelaksanaan sila yang didasari oleh kehendak yang kuat yaitu tekad untuk kebaikan diri manusia itu sendiri (an sich). Sila dilaksanakan sebagai kewajiban dengan tanpa syarat dan tanpa pamrih, murni dan a priori, murni untuk kewajiban itu. Dan hal ini sebagai bentuk penyelarasan manusia dengan Allah, dengan melaksanakan moralitas yang dilandasi oleh tekad yang tanpa syarat sebagai sebuah kewajiban hidup.
\end{abstract}

Kata kunci: Filsafat Moral Immanuel Kant, Perzinahan, Pancasila Buddhis

\begin{abstract}
Adultery is seen from a religious aspect as an act that violates the $3 r d$ principle of the Buddhist Pancasila, namely: "I am determined to train myself to avoid the act of adultery". The conditions for an act to be referred to as adultery are: 1) there is an object of violation (the act); 2) the offender (the perpetrator); 3) the physical means ready as a condition for the indulgence of the lust (partner in doing the action); and 4) the action) is fulfilled or accomplished. Adultery is caused by attachments to objects (lobha) and delusion (moha), and is influenced by bad thoughts (Akusalacetasika) namely Ahirika (not ashamed of doing evil), and Anottappa (not afraid of the consequences of doing evil). So that the result of adultery is having enemies, being disliked by everyone, fear, a tendency to be female or gender neutral in the next life. And for the most part, acts
\end{abstract}


of adultery can encourage a person to be reborn in the demon realm (Peta) and raksana (Asurakaya) when with the power of Lobha who leads, and reborn in the animal realm (Tiracchanayoni) with the dominating Moha power. The achievement of Immanuel Kant's moral philosophy, that the act of adultery is an immoral act because it does not make humans good but instead makes human life bad. So that it must be fought by carrying out a priori or obligatory rules of morality so that human life becomes good. The implementation of precepts which is based on a strong will, namely the determination for the good of the human being himself (an sich). Precepts are performed as an obligation unconditionally and without strings attached, pure and a priori, purely for that obligation. And this is a form of conformity between humans and God, by carrying out morality which is based on unconditional determination as an obligation of life.

\section{Keywords: Immanuel Kant's Moral Philosophy, Adultery, Buddhist Pancasila}

\section{PENDAHULUAN}

Perzinaan adalah hubungan seksual yang tidak sah yang dilakukan oleh laki-laki dan perempuan di luar ikatan perkawinan. Berdasarkan kepatutan di dalam masyarakat perbuatan perzinaan merupakan suatu hal yang dilarang karena dapat menimbulkan keresahan di dalam masyarakat. Perzinahan menurut pandangan norma adat pada sebagian besar masyarakat di wilayah Indonesia adalah suatu hal yang dilarang. Dari sudut pandang ajaran agama-agama yang ada di Indonesia juga memandang perbuatan perzinahan merupakan perbuatan yang dilarang. Dalam pandangan agama Islam seperti yang terdapat di dalam penelitian yang dilakukan oleh Hilman, (2014: 5), menyatakan bahwa larangan zina antara lain terdapat dalam surat Al-Isra ayat 32 sebagai berikut: Artinya: Dan janganlah kamu mendekati zina; sesungguhnya zina itu adalah suatu perbuatan yang keji. Dan suatu yang buruk. (Q.S. AlIsra':32).

Dalam hukum pidana Hindu seperti tertuang dalam MDS VIII. 367 dan 372, Manawa Dharmasastra VIII.359, Menyatakan "Seorang bukan Brahmana diancam dengan hukuman mati karena perbuatan berzina, karena istri dari keempat warna itu harus dijaga benar-benar" (Pudja dan Sudharta. 2002). Hal tersebut menjelaskan bahwa di dalam agama Hindu juga melarang para umatnya untuk tidak melakukan perbiatan perzinaan karena sanksi atau hukumannya sangat berat. Selanjutnya dalam pandangan Buddhism tindakan perzinaan merupakan pelanggaran terhadap Pancasila Buddhis yaitu sila ke-3 yang berbunyi: "Kãmesu micchãcãrã veramanî sikkhãpadai் samãdiyãmi" yang artinya bahwa Aku bertekad untuk melatih diri menghindari perbuatan perzinahan (Paritta Suci, 2017:18).

Perbuatan perzinahan dari sudut pandang hukum positif yang berlaku di Indonesia yaitu KUHP, diatur dapam pasal Pasal 284 KUHP. Dalam pasal tersebut menjelaskan bahwa perbuatan perzinaan dapat dikenai sanksi apabila pelaku perzinahan dilakukan oleh orang-orang - yang salah satu atau kedua-duanya - terikat tali perkawinan, sehingga apabila ada laki-laki dan perempuan yang masing-masing tidak terikat tali perkawinan melakukan perzinahan, maka tidak dapat dikenai sanksi atau tidak dapat dipidana dengan kata lain perbuatan tersebut bukan delik perzinahan. Adapun sanksi yang dapat dijatuhkan maksimal hanya 9 sembilan bulan pidana penjara (Ismayawati, 2016: 91).

Beberapa waktu yang lalu masyarakat dihebohkan dengan sebuah pernyataan pada sebuah disertasi seorang mahasiswa Program Doktor UIN Sunan Kalijaga Yogyakarta (Abdul Aziz), dengan judul Konsep Milk alYamin Muhammad Syahrur sebagai Keabsahan Hubungan Seksual Nonmarital, yang mana inti dari disertasi tersebut adalah pengabsahan hubungan intim di luar pernikahan dengan syarat tertentu. Abdul Aziz 'mengamini"' konsep pemikir liberal asal Syria Muhammad Syahrur bahwa hubungan seksual nonmarital bukanlah merupakan perbuatan zina. Seturut Syahrur, hubungan seksual di luar nikah baru dikatakan sebagai perbuatan zina jika hal itu dilakukan secara terbuka atau ekshibisi. Sehingga apabila dilakukan di tempat tertutup, perbuatan itu tidak bisa dikatakan sebagai perbuatan zina dan dianggap tidak 
melanggar syariat Islam (Huriyah, Jawa Pos pada Selasa, 3 September 2019).

$$
\text { Pernyataan tersebut menuai }
$$

kontroversi dalam masyarakat, masyarakat dengan sangat cepat merespons dan menggugat statement tersebut karena dianggap bertentangan dengan norma adat yang ada di dalam masyarakat Indonesia maupun norma agama manapun. Dampak secara luas dari pernyataan dalam disertasi tersebut adalah munculnya perilaku daripada generasi muda yang secara mentah menelaah pernyataan tersebut, selain itu keresahan bagi pihak-pihak yang memiliki pendapat yang tidak sependapat dengan petnyataan tersebut. Kekawatiran secara lebih luas adalah terjadinya perubahan persepsi dan perilaku para generasi muda yang secara umum atau biasanya sikap para generasi muda saat ini adalah mudah menerima suatu pernyataan dengan begitu saja dan tidak ditelaah terlebih dahulu. Hal tersebut menurut peneliti merupahan suatu hal yang membahayakan jika para generasi muda menganggap pernyataan tersebut dengan serta merta dan mengiyakannya. Hal ini akan berdampak merosotnya moralitas generasi muda, dan secara lebih luas terkait dengan martabat manusia pada umumnya. Sehingga penelitian ini dianggap sangat perlu untuk menelaah lebih lanjut mengenai perzinahan dari sudut pandanga Buddhism dan filsafat moral Immanuel Kant.

Manusia, menurut Immanuel Kant, adalah makhluk yang bermartabat. Dasar martabat manusia terletak dalam kenyataan bahwa manusia adalah persona dan otonom. Sebagai persona, manusia manusia mampu menentukan dirinya. Penentuan diri ini terjadi karena manusia memiliki akal budi. Dengan akal budinya, manusia mampu menciptakan hukum moral yang bukan hanya berlaku bagi dirinya tetapi juga bagi segenap makhluk rasional. Dengan demikian, manusia adalah makhluk yang otonom. Persona dan otonomi dalam diri manusia menjadi dasar martabat manusia. (Sales, 2014:83).

Beberapa usaha dilakukan untuk mempertahankan martabat manusia dalam segala bidang, baik melalui pendidikan, penegakan hukum formal maupun non formal. Semua itu dilakukan untuk melindungi bahwa martabat manusia adalah sangat penting untuk tetap menjadi baik dipertahankan untuk kebaikan masyarakat. Peneliti bermaksud untuk memberikan analisa tentang perbuatan perzinahan menurut pandangan Buddhism. Sedangkan pisau analisanya adalah menggunakan filsafat moral Immanuel Kant.

\section{METODE PENELITIAN}

Penelitian ini menggunakan metode penelitian kualitatif. Penelitian kualitatif adalah metode penelitian yang digunakan untuk meneliti pada kondisi obyek yang alamiah, (sebagai lawannya adalah eksperimen) dimana peneliti adalah sebagai instrumen kunci, analisa data bersifat induktif, dan hasil penelitian kualitatif lebih menekankan makna dari pada generalisasi (Sugiyono, 2018:1).

Jenis penelitian atau pendekatan penelitian merupakan Studi Kepustakaan (Library Research). Studi kepustakaan merupakan suatu studi yang digunakan dalam mengumpulkan informasi dan data dengan bantuan berbagai macam material yang ada di perpustakaan seperti dokumen, buku, majalah, kisah-kisah sejarah, dsb (Mardalis:1999). Studi kepustakaan juga dapat mempelajari beberbagai buku referensi serta hasil penelitian sebelumnya yang sejenis yang berguna untuk mendapatkan landasan teori mengenai masalah yang akan diteliti (Sarwono:2006).

Studi pustaka dilakukan dengan pengkajian mengenai konsep dan teori yang digunakan berdasarkan literatur yang tersedia, terutama dari artikel-artikel yang dipublikasikan dalam berbagai jurnal ilmiah. Kajian pustaka berfungsi untuk membangun konsep atau teori yang menjadi dasar studi dalam penelitian (Sujarweni, 2014:57).

Penelitian berusaha mengurai tentang perzinahan dalam Pancasila Buddhis menurut perspektif filsafat moral Immanual Kant. Penggunaan teori filsafat Immanuel Kant secara operasional digunakan untuk menemukan jawaban atas pertanyaan tentang perzinahan. Kemudian penelitian ini juga akan berusaha melakukan analisa terkait dengan perzinahan menurut Buddhism. 
Sumber data dalam penelitian pustaka ini terdapat dua jenis literatur yang digunakan, yaitu, primer dan sekunder. Literatur primer terdiri dari karya Imanuek Kant tentang filsafat moral. Selain itu peneliti juga menggunakan kitab-kitab dalam agama Buddha yang berkaitan dengan perzinahan, penyebab suatu perbuatan perzinahan, peran serta pikiran dan akibat dari perbuatan perzinahan. Sedangkan sumber data sekunder terdiri dari karya-karya penelitian terdahulu terkait dengan perzinahan, dan buku-buku, jurnal, dan berita-berita dari media massa yang mendukung kelengkapan data primer.

\section{PEMBAHASAN}

\section{Perzinahan Dalam Pandangan Buddhism}

Dalam Buddhism, asyarakat dibedakan menjadi dua jenis yaitu garavasa dan pabbajita. Garavasa adalah umat lakilaki atau perempuan yang menjalani kehidupan berumah tangga. Sedangkan pabbajita adalah laki-laki atau perempuan yang menjalani kehidupan terlepas dari kehidupan duniawi yang disebut dengan bhikkhu, bhikkhuni, samanera dan samaneri. Dalam tatanan tereraturan hidup di dalam masyarakat kedua jenis masyarakat ini masing-masing menjalankan sila atau peraturan yang berbeda. Para pabbajita menjalankan Patimokkha-sila yang berisi sebanyak 227 butir peraturan yang harus dijalankan. Sedangkan para garavasa atau masyarakat perumah tangga menjalankan lima sila yang disebut dengan Pancasila Buddhis. Masyarakat menjalankan lima sila ini dengan tujuan untuk menciptakan kereraturan dan ketertiban di dalam kehidupannya.Adapun kelima sila tersebut adalah sebagai berikut:
1. Panatipata veramani sikkhãpadam samãdiyãmi;
2. Adinnadana veramani sikkhãpadam samãdiyãmi;
3. Kãmesu micchãcãrã veramanî sikkhãpadai் samãdiyãmi;
4. Musavada veramani sikkhãpadam samãdiyãmi;

5. Suramerayamajjapamadatthana veramani sikkhãpadam samãdiyãmi. ((Dighanikaya III. 235))

Artinya:
1. Aku bertekad untuk melatih diri menghindari perbuatan pembunuhan;

2. Aku bertekad untuk melatih diri menghindari perbuatan pencurian;

3. Aku bertekad untuk melatih diri menghindari perbuatan perzinahan;

4. Aku bertekad untuk melatih diri menghindari perbuatan pendustaan;

5. Aku bertekad untuk melatih diri menghindari perbuatan minuman keras dan barang-barang yang memabukkan.(Dighanikaya III. 235)
Perzinahan
dalam
Buddhism

merupakan suatu perbuatan yang melanggar sila ke-3 Pancasila Buddhis yang berbunyi: "Kãmesu micchãcãrã veramanî sikkhãpadam samãdiyãmi" yang artinya "Aku bertekad untuk melatih diri menghindari perbuatan perzinahan". Perbuatan perzinahan dijelaskan di dalam Kitab Anguttara Nikaya II (A. IV, 53), bahwa seorang suami atau istri yang digambarkan sebagai raksasa dan raksasi dengan karakteristik salah satunya melakukan perilaku seksual yang tidak benar.

Dalam Kitab Anguttara Nikaya III, (A. III: 25), menjelaskan tentang moralitas bagi umat awam atau umat perumah tangga. dikatakan bahwa perilaku apa saja yang hendaknya dilaksanakan oleh umat awam sebagai landasan moralitas dalam kehidupan bermasyarakat, sebagai berikut:

“.....jika pengikut awam tidak menghancurkan kehidupan, tidak mengambil apa yang tidak diberikan, tidak melakukan perbuatan asusila, tidak berbicara tidak benar, tidak minum anggur, minuman keras dan semua yang bersifat meracuni yang menjadikan landasan kelalaian, pengikut awan itu menunjukan moralitas" (A. VIII: 25).

kutipan tersebut, bahwa seorang umat harus menjalankan lima sikap yaitu: 1) tidak membunuh; 2) tidak mencuri; 3) tidak melakukan perzinahan; 4) tidak berbohong; dan 5) tidak mabuk-mabukan yang menyebabkan kelalaian. Kelima hal tersebut merupakan peraturan (sila) yang wajib untuk dilaksananan oleh umat awam. Apabila kelima hal tersebut dilaksanakan maka dikatakan bahwa umat tersebut memiliki moralitas yang baik. 
Berkaitan dengan perbuatan perzinaan, yang merupakan peraturan (sila) ke-tiga dari peraturan tersebut. Dijelaskan di dalam kitab Anguttara Nikaya II (A. IV: 53) tentang jenis pernikahan, sebagai berikut:

"Perumah tangga, ada empat jenis pernikahan. Apakah yang empat itu? Raksasa hidup bersama dengan raksasi, raksasa hidup bersama dengan dewi, dewa hidup bersama dengan raksasi. dewa hidup bersama dengan dewi”(A. IV: 53).

Selanjutnya dijelaskan, bahwa dewa dan dewi merupakan perumpanaan jenis suami dan istri yang memiliki karakter yang menjauhkan diri dari pembunuhan makhluk lain, mengambil apa yang tidak diberikan, melakukan perilaku seksual yang tidak benar, berbicara bohong, dan bermanja-manja dalam minuman keras. Dia luhur, berwatak baik, dia diam di rumah dengan hati yang bebas dari noda kekikiran. dan tidak melecehkan Pertapa dan Brahmana.

Sedangkan raksasa dan raksasi merupakan sebuah perumpamaan jenis suami dan istri yang memiliki karakter suka membunuh makhluk lain, mengambil apa yang tidak diberikan, melakukan perilaku seksual yang tidak benar, berbicara bohong, dan bermanja-manja dalam minuman keras. Tidak bermoral, berwatak buruk berdiam di rumah dengan hati yang terobsesi noda kekikiran, melecehkan Pertapa dan Brahmana. Karakter raksasa dan raksasi tersebut salah satunya dalamnya adalah melakukan perilaku seksual yang tidak benar.

Adapun perilaku seksual yang tidak benar dijelaskan di dalam Kitab Khuddakapatha I, Bab II tentang Sepuluh Peraturan Latihan (Dasasikkhãpadam), syair ke - 29, 32, 35, 44, 54. Kutipan dari Kitab Suci Khuddakapatha I, Bab II tersebut, perbuatan perzinahan disebut dengan istilah "apa yang bukan kehidupan suci (ketidakmurnian)". Perbuatan perzinahan dilakukan dengan kemauan pelaku sendiri dan bukan atas dasar perintah dari pihak lain. Terdapat empat syarat suatu perbuatan dikatakan sebagai perbuatan perzinaan yaitu: 1) ada objek pelanggaran (perbuatannya); 2) si pelanggar (pelaku); 3) sarana fisik yang siap sebagai kondisi untuk pemuasan nafsu itu (pasangan dalam melakukan perbuatan itu); dan 4) tindakan itu) terpenuhi atau terlaksana. Dengan kutipan dan penjelasan sebagai berikut:

Syair 29: "Dalam hal yang bermula dengan dengan apa yang bukan kehidupan suci (ketidakmurnian), hanya dengan tangan sendiri sebagai sarana saya yang mungkin (bukan lewat perintah dan lian-lainnya)".

Syair ke-29 tersebut menjelaskan, disebut sebagai perbuatan perzinaan yang dalam hal ini disebut dengan istilah "apa yang bukan kehidupan suci atau ketidakmurnian" jika dilakukan atas dasar kemauan sendiri dan bukan atas perintah pihak lain. Selanjutnya perbuatan perzinaan dilakukan dengan atau melalui sarana tubuh atau badan nya sendiri.

Syair 32: "Dalam hal apa yang bukan kehidupan suci (ketidakmurnian) ada empat faktor, yaitu: ada objek pelanggaran, kesadaran pemuasan nafsu terbentuk, (si pelanggar) memiliki sarana fisik yang siap sebagai kondisi untuk pemuasan nafsu itu, (tindakan itu) terpenuhi".

Syair ke-32 menjelaskan, bahwa suatu perbuatan dikatakan sebagai perzinahan jika memenuhi empat syarat sebagai berikut: 1) ada objek pelanggaran (perbuatannya); 2) si pelanggar (pelaku); 3) sarana fisik yang siap sebagai kondisi untuk pemuasan nafsu itu (pasangan dalam melakukan perbuatan itu); dan 4) tindakan itu) terpenuhi atau terlaksana. Dapat dijelaskan, jika ada suatu perbuatan yang dilakukan dengan kemauan sendiri dan dengan menggunakan sarana badan atau tubuh nya sendiri, kamudian ada pelaku yang melakukan perbuatan itu, ada sarana fisik sebagai pemuas nafsu atau pasangan yang dipergunakan sebagai pemuas nafsu, dan ada tindakan atau perbuatan itu terlaksana. Maka suatu perbuatan itu dapat dikatakan sebagai perzinahan. Dengan kata lain apabila salah satu dari ke-empat syarat tersebut tidak terpenuhi maka suatu perbuatan tidak bisa dikatakan sebagai perzinahan.

Kemudian tentang sarana fisik atau pasangan yang dapat memuaskan nafsu disini dijelaskan di dalam Sigalaka Sutta (D.III: 31), bahwa yang dimaksudkan adalah orang yang selain suami atau istrinya sendiri. Dalam hal 
ini suami atau istri yang terikat secara sah dalam ikatan pernikahan. Selain itu orang yang tidak atau belum memiliki pasangan (tidak/belum menikah) yang melakukan hubungan suami-istri dengan orang lain (lakilaki atau perempuan).

Syair 35: "Sehubungan dengan asalnya: semua, apa yang bukan kehidupan suci (ketidakmurnian) hanya memiliki asal mula tunggal, yaitu lewat tubuh-bersama-kesadaran".

Syair 35 menjelaskan bahwa asal mula tunggal suatu perbuatan perzinahan yaitu lewat tubuh-bersama-kesadaran. Perbuatan Perzinahan dilakukan melalui tubuh bersama dengan adanya peran serta dari kesadaran (pikiran). Kitab Dhammapada Bab I (Yamaka-vagga), ayat 1 dan 2 tentang peranan pikiran dalam hidup manusia. Perbuatan perzinahan berasal dari adanya pikiran yang buruk tentang hal-hal yang berhubungan dengan perilaku sex menyimpang. Artinya adanya perbuatan perzinahan karena ada pikiran negatif yang mengawalinya, apabila pikiran negatif tidak ada maka tidak aka nada perbuatan perzinahan yang terjadi.

Mengapa pikiran negatif tentang perilaku sex menyimpang bisa muncul, karena pikiran menangkap objek melalui indera-indera yang ada. Objek-objek tersebut dapat berupa bau-bauan, pemandangan atau bentuk sesuatu yang dapat dilihat oleh mata, suara-suara yang dapat didengar oleh telinga, maupun sentuhan-sentuhan yang dapat dirasakan oleh kulit. Objek-objek tersebut tentunya adalah objek yang berkaitan atau objek yang dapat menimbulkan perilaku sex menyimpang. Objek-objek tersebut di tangkap oleh indera-indera kemudian sampaikan kepada pikiran (kesadaran) melalui proses berpikir. Pikiran menerima dan memeriksa objek yang diterima tersebut, dan disinilah letak kesimpulan atau keputusan akan dihasilkan, karena pada tahapan ini terdapat bentuk-bentuk pikiran yang buruk (Akusalacetasika) yang berperan dan akan mempengaruhi keputusan yang dihasilkan. Bentuk-bentuk pikiran yang mempengaruhi pikiran dalam mengambil keputusan untuk melakukan perbuatan perzinahan antara lain adalah: 1) Moha atau kebodohan/kegelapan bantin; 2) Ahirika atau tidak malu berbuat jahat; 3) Anottappa atau tidak takut akan akibat perbuatan jahat; dan 4) Lobha atau keserakahan dan kemelekatan.

Selanjutnya mengapa pikiran dapat melahirkan perbuatan perbuatan yang buruk atau dalam hal ini adalah perzinahan. Menurut Kaharuddin (2015: 7), tentang karakteristik alami dari pikiran, maka karakteristik dari pikiran yang ke-3 yaitu (thitassa-annathattanpannayati), yang artinya bahwa pikiran sellau berubah-ubah, dari baik menjadi buruk pada detik berikutnya menjadi baik lagi buruk lagi dan sebagainya. Selain itu dengan adanya hukum Tilakkhana (tiga corak umum), Anicca, Dukkha, Anatta, pikiran dari detik ke detik berikutnya adalah tidak tetap yang artinya setelah pikiran menerima objek maka objek tersebut akan mengalami muncul lagi hilang dan muncul lagi, sehingga karena hal ini akan menimbulkan kesedihan karena ketidak mampuan untuk merespon atau menuruti kemauan atau keinginan untuk menuruti keinginan nafsu indera atas objek yang diterima tersebut.

Syair 44: "Buah-buah dari tidak melakukan apa yang bukan kehidupan suci (ketidakmurnian) adalah hal-hal seperti misalnya bebas dari musuh, disayangi semua orang, memperoleh makanan, minuman, pakaian, tempat tinggal, dsb. Bebas dari rasa takut, tidak ada kecenderungan untuk jenis kelamin perempuan atau jenis kelamin netral, bebas dari kemarahan, tidak dipandang rendah, lengkap indrianya, dan sebagainya".

Syair 44, tentang akar perbuatan perzinahan yang dilakukan oleh tubuh bersama dengan kesadaran (pikiran) tersebut adalah karena adanya keserakahan dan kebodohan batin. Kitab Dighanikaya (III: 275), menjelaskan tentang tiga akar perbuatan buruk (Akusala-mula 3), dari ke-tiga akar perbuatan buruk tersbut, maka akar yang mempelopori perbuatan perzinahan adalah akar yang ke-1 dan akar ke-3 yaitu Lobha dan Moha. Lobha: secara etika berarti ketamakan atau keserakahan. Keserakahan disini dapat diartikan tidak puas dengan apa yang 
dimilikinya. Dalam hal ini tidak puas dengan istri atau suami yang dimilikinya, atau tidak puas dengan sikap istri atau suaminya, tidak puas dengan penghasilan atau jabatan istri atau suaminya. Kondisi ini dapat menjadi pendorong suatu perbutan perzinahan.

Secara psikologis lobha adalah terikatnya pikiran oleh objek-objek, disebut Tanhã atau keinginan, disebut Kãma atau nafsu indera, disebut juga Rãga atau hawa nafsu. Dapat dijelaskan bahwa ketika pikiran menerima objek melalui indera-indera maka oleh karena adanya keterikatan/melekat pada objek tersebut (misalnya objeknya adalah wanita/laki-laki yang cantik/menarik) maka munculkan keinginan untuk memilikinya. Dengan disertai oleh bentuk-bentuk pikiran yang buruk (Akusala-cetasika), imajinasiimajinasi yang menyimpang tentang objek tersebut dan muncullah hawa nafsu sex yang menyimpang. Kemelekatan pada objek inilah dapat mendorong suatu perbuatan perzinahan.

Akar perbuatan buruk ke-3 yaitu Moha yang berarti kebodohan batin atau kurang mengerti, juga disebut Avijjã (tidak tahu), atau Ańńana (tidak berpengetahuan) atai Adassana (tidak Nampak/tidak mengerti). Dapat dijelaskan bahwa kebodohan atau kegelapan batin yang menyebankan seseorang tidak mampu untuk melihat ajaran kebenaran dengan baik. Seseorang tidak mampu menelaah ajaran bahwa perbuatan perzinahan itu tidak baik, bahwa perbuatan tersebut melanggar sila, bahwa perbuatan tersebut akan membawa akibat yang buruk bagi keluarga maupun bagi kehidupan di masa datang. Kebodohan inilah yang mampu mendorong seseorang dapat melakukan perbuatan perzinahan.

Syair 54: "Sehubungan dengan akar: sebagaimana apa yang bukan kehidupan suci (ketidakmurnian) memiliki keserakahan dan kebodohan batin sebagai akarnya".

Syair 54, tentang buah atau akibat dari melakukan perbuatan perzinahan. Akibat dari perbuatan perzinahan adalah hal-hal seperti misalnya memiliki musuh, tidak disukai semua orang, adanya rasa takut, adanya kecenderungan untuk jenis kelamin perempuan atau jenis kelamin netral pada kehidupan berikutnya, diliputi oleh kemarahan, dipandang rendah, dan sebagainya.

Jika dibicarakan secara sebagian besar maka hasil atau akibat dari perbuatan perzinahan dapat mendorong suatu makhluk terlahir di alam setan (Peta) dan raksana (Asurakaya) dengan kekuatan Lobha, dan terlahir di alam binatang (Tiracchanayoni) dengan kekuatan Moha.

Dalam Sigalaka Sutta (D.III: 31), menjelaskan tentang kewajiban-kewajiban sebagai seorang suami dan istri. Bahwa seorang suami atau istri memiliki kewajiban untuk menghormati pasangannya dengan cara: tidak merendahkannya, setia kepadanya, memberikan hal-halnya, dan bersikap baik. Selanjutnya secara lebih detail seorang suami atau istri harus saling setia, menjaga kepercayaan dan tidak diperkenankan untuk melakukan hubungan selain dengan suami atau istrinya sendiri. Dapat di artikan bahwa perbuatan perzinahan adalah perbuatan seksual yang dilakukan bukan dengan pasangannya sendiri, apalagi seseorang yang tidak atau belum memiliki pasangan tentu saja hal itu sangat di larang.

Asal muasal perbuatan perzinaan adalah melalui lewat tubuh bersama dengan adanya peran serta dari kesadaran (pikiran). Kitab Dhammapada Bab I (Yamaka-vagga), ayat 1 dan 2:

Ayat 1: "Manopubbangama dhamma, manosettha manomaya manasa ce padutthena, bhasati va karoti va tato nam dukkhamanveti, cakkamva vahato padam"

Artinya: Pikiran adalah pelopor dari segala sesuatu, pikiran adalah pemimpin, pikiran adalah pembentuk. Bila seseorang berbicara atau berbuat dengan pikiran jahat, maka penderitaan akan mengikutinya bagaikan roda pedati mengikuti langkah kaki lembu yang menariknya.

Ayat 2: "Manopubbhangama dhamma, manosettha manomaya manasa ce pasannena, bhasati va karoti va. tato nam sukhamanvetti, chayava anupayini"

Artinya: Pikiran adalah pelopor dari segala sesuatu, pikiran adalah pemimpin, pikiran adalah pembentuk. Bila seseorang berbicara atau berbuat dengan pikiran murni, maka kebahagiaan akan mengikutinya bagaikan 
baying-bayang yang tak pernah meninggalkan bendanya.

Syair di atas menjelaskan bahwa semua perbuatan baik yang dilakukan melalui ucapan maupun perbuatan badan jasmani dimulai dari pikiran. Maka dijelaskan bahwa pikiran memegang peranan kunci utama dari terjadinya suatu perbuatan. Pikiran memegang peranan yang sangat penting dari teraplikasinya suatu perbuatan baik itu perbuatan baik maupun perbuatan buruk. Dalam hal perbuatan perzinaan, sebelum perbuatan itu terjadi atau dilaksanakan maka didahului oleh adanya pikiran negatif tentang perbuatan permuasan nafsu sex yang menyimpang.

Selanjutnya mengapa pikiran dapat melahirkan perbuatan yang baik dan perbuatan yang buruk, Kaharuddin (2015: 7), menjelaskan tentang karakteristik alami dari pikiran (yang dalam bahasa Pali disebut dengan "citta" atau kesadaran). Bahwa pikiran memiliki tiga karakter yang alami yaitu: 1) tertampak dilahirkan/munculnya (uppado-pannayati); 2) tertampak lenyapnya (vayo-pannayati); dan 3) selama pikiran itu masih ada maka akan tertampak perbahanperubahan atas pikiran itu (thitassaannathattan- pannayati). Pikiran juga di cengkeram oleh hukum Tilakkhana (tiga corak umum), yaitu: Anicca, Dukkha, dan Anatta. Anicca: pikiran itu tidak kekal, tidak tetap, tidak kuat, tidak dapat bertahan untuk selamanya. Dukkha: oleh karena pikiran tidak dapat bertahan selamanya, maka pikiran itu selalu timbul-padam, datang-pergi dan berganti-ganti seterusnya yang akan menimbulkan kesedihan atau dukkha. Anatta: bahwa pikiran itu tanpa inti yang kekal, tidak dapat berdiam selamanya.

The Dhammasangani (Vol. I: 13), menjelaskan entang tiga Dhamma atau tiga jenis keadaan pikiran yang dapat mempengaruhi sikap dan perilaku manusia sebagai berikut: 1) Kusala-dhamma: adalah keadaan yang baik yang meliputi Kusala-citta 12, dan Cetasika 38; 2) Akusala-dhamma: adalah keadaan yang tidak baik/jahat, yaitu Akusala-citta 12, dan Cetasika 27; dan 3) Abyakata dhamma: adalah netral, bukan baik dan bukan tidak baik/jahat yang meliputi
Vipaka-citta 36, Kiriya-citta 20, Cetasika 28, Rupa 28, dan Nibbhana.

Cetasika adalah faktor-faktor batin atau bentuk-bentuk batin yang selaku bersekutu/mempengaruhi keberadaan atau jenis pikiran. Perbuatan perzinahan merupakan perbuatan buruk yang dipengaruhi oleh bentuk pikiran yang buruk (Akusalacetasika). Kaharuddin (2015: 127), menjelaskan terdapat 4 kelompok bentuk pikiran yang buruk yaitu: 1) Mocatukacetasika: Moha (kebodohan), Ahirika (tidak malu berbuat jahat), Anottappa (tidak takut akan akibat perbuatan jahat), Uddhacca (kegelisahan); 2) Lotika-cetasika: Lobha (keserakahan/kemelekatan), Ditthi (kekeliruan/kepalsuan), Mana (kesombongan); 3) Docatuka-cetasika: Dosa (kebencian), Issa (irihati), Maccahariya (egois), Kukkucca (kawatir); 4) Thidukacetasika: Thina (kemalasan), Middha (kelelahan); 5) Vicikiccha-cetasikaa: Vicikiccha (keragu-raguan).

Sedangkan akar perbuatan yang dilakukan oleh tubuh bersama dengan kesadaran (pikiran) tersebut adalah karena adanya keserakahan dan kebodohan batin.

Kitab Dighanikaya III. 275, menjelaskan tentang tiga akar perbuatan buruk (Akusala-mula 3), yaitu:

1. Lobha: secara etika berarti ketamakan, tetapi secara psikologis terikatnya pikiran oleh objek-objek. Inilah yang disebut Tanhã atau keinginan, disebut Kãma atau nafsu indera, disebut juga Rãga atau hawa nafsu.

2. Dosa: secara etika berarti kebencian, secara psikologi berarti pukulan yang berat dari pikiran terhadap objek, yaitu pertentangan atau konflik. Mengenai ini terdapat dua macam nama yaitu: Patigha atau dendam atau tidak senang, dan Byãpada atau kemauan jahat.

3. Moha: berarti kebodohan batin atau kurang mengerti. Ia juga disebut Avijja (tidak tahu), atau Ańńana (tidak berpengetahuan) atai Adassana (tidak Nampak/tidak mengerti).

Buah dari perbuatan perzinaan adalah hal-hal seperti misalnya memiliki musuh, tidak disukai semua orang, adanya rasa takut, adanya kecenderungan untuk jenis kelamin 
perempuan atau jenis kelamin netral pada kehidupan berikutnya, diliputi oleh kemarahan, dipandang rendah, dan sebagainya.

Akibat dari akar perbuatan buruk dijelaskan secara sebagian besar sebagai berikut (Kitab Dighanikaya III: 275):

1. Yebhuyyayena hi satta pettivisayam uppajjanti.

Artinya: Semua makhluk dilahirkan menjadi setan (Peta) dan raksana (Asurakaya) dengan kekuatan Lobha.

2. Dosena hi candajatataya dosasadisam nirayam uppajjanti.

Artinya: Semua makhluk dilahirkan di alam neraka (Niraya) dengan kekuatan Dosa.

3. Mohena hi niccasammulaham tiracchanayoniyam uppajjanti.

Artinya: Semua makhluk dilahirkan menjadi binatang (Tiracchanayoni) dengan kekuatan Moha.

\section{Perzinahan Dalam Pandangan filsafat Moral Immanuel Kant}

Di dalam mengembangkan etikanya, Kant bertolak belakang dalam pendekatan dengan filsuf sebelumnya. Ia menolak pola etika sebelumnya yang berpusat pada pertanyaan mengenai "kebahagiaan". Dan etika sebelumnya berkepentingan untuk mengajak manusia cara hidup yang harus dilalui agar bahagia. Hal tersebut bagi Kant bukan persoalan mendasar yang menentukan dalam moralitas, melainkan pertanyaan: "apa yang membuat manusia baik?" Pertanyaan ini kemudian dirumuskan dalam inti etikanya menjadi: "apa yang baik pada dirinya sendiri?"'(Gusmian, 2014: 60).

Filsafat moral atau etika yang murni adalah etika yang bersifat apriori. Etika ini menyibukkan diri hanya dengan perbagai macam perumusan dan pembenaran atas berpagai prinsip moral dengan berbagai macam istilah seperti "wajib", "kewajiban", "baik atau buruk", "benar" dan "salah". Etika apriori ini disebut sebagai metafisika kesusilaan (Metaphysik der Sitten). Akan tetapi etika selain bersifat apriori juga bersifat empiris atau aposteriori dan oleh Kant disebut sebagai antropologi praktis (prktische Anthroplogie).(Tjahjadi, 1991: 46).
Kant mengatakan bahwa moralitas adalah hal yang menyangkut baik dan buruk, tetapi bukan sembarang yang baik dan buruk, melainkan, dalam bahasa Kant, apa yang baik pada dirinya sendiri tanpa pembatasan. Sedang kebaikan yang tanpa pembatasan adalah kehendak baik. Berbeda dengan hal itu, adalah bakat rohani, ciri perangai dan sifat-sifat watak seseorang hanya akan mempunyai nilai moral apabila diabdikan pada kehendak baik itu; kehendak yang menentukan apakah watak orang dipakai dengan baik atau buruk. Syarat kebaikan berbagai sifat manusia adalah kehendaknya yang baik (Suseno, 1997: 143).

Menurut Kant, tindakan seseorang adalah baik secara moral bukan lantaran itu dilakukan berdasarkan kecenderungan spontan atau selera pribadi, melainkan lantaran perbuatan itu dilakukan demi untuk mewajiban semata-mata. Sehingga seseorang yang bertindak demi hukum moral berarti bertindak berdasarkan kewajiban sebagai pengejawantahandari kehendak baik, dan karenanya tidakan itu baik secara moral. Apa yang diharuskan secara moral adalah selalu suatu kehendak, dan suatu tindakan hanya merupakan objek atau realitas fisik dari keharusan moral sejauh dengan tindakan itu kehendak dapat berkembang penuh. Dengan demikian, ciri khas paham kewajiban Kant adalah bahwa yang diharuskan itu selalu kehendak.(Tjahjadi, 1991: 51).

Immanuel Kant menaruh dasar penilaian moral pada deskripsi mengenai kehendak baik. Ia memandang bahwa kehendak baik merupakan unsur yang penting dalam menilai baik-buruk, benar-salah suatu tindakan moral. Hal ini sesuai dengan pandangannya bahwa kehendak baik merupakan sebuah keniscayaan. Artinya, tidak ada yang baik secara mutlak selain kehendak baik itu sendiri. Kehendak baik dipandang sebagai kehendak yang mengandung kebaikan pada dirinya sendiri (an sich). Lantas dapat dipahami bahwa kehendak baik tidak tergantung pada hal-hal lain atau kecenderungan-kecenderungan yang ada di luar dirinya. setiap kehendak baik yang muncul dan dijadikan landasan tindakan moral seseorang, maka akan senantiasa memunculkan kebaikan-kebaikan moral, 
karena kehendak baik itu sifatnya tanpa pamrih, tanpa syarat. Dalam konteks ini kita dapat dipahami bahwa Immanuel Kant menyelaraskan antara moralitas dengan kehendak. Ia memiliki pandangan bahwa bagi manusia yang pada hakikatnya memiliki rasio, sudah seharusnya moralitas sejalan dengan kehendak baik. Secara lebih lanjut, Immanuel Kant menjelaskan bahwa kehendak baik yang mengalir dari kesadaran rasio tersebut akan mengarahkan manusia pada pemenuhan akan kewajibannya. Lantas disini moralitas dipahami sebagai nilai yang mengalir dari kehendak baik manusia dan upayanya menggenai kewajiban hidupnya. Suatu tindakan moral dapat dinyatakan baik ataupun benar secara moral bila sejalan dengan kehendak baik dan kesesuaian dengan kewajiban seseorang, demikian pula sebaliknya (Ayub, 2020: 239-240).

Selanjutnya Kant menegaskan bahwa suatu tindakan yang dilakukan berdasarkan kewajiban itu memiliki nilai moralnya dari prinsip formal atau maksim formal. Maksim yang memberikan nilai moral bagi tindakan kita adalah maksim yang memerintahkan kita melakukan begitu saja kewajiban kita apapun wujud kewajiban itu. Seseorang disebut "baik" dalam arti moral apabila ia menerima (atau menolak) maksim material yang sesuai (atau bertentangan) dengan maksim formal, yang menghendaki agar tindakan dilakukan demi kewajiban itu sendiri. Bertindak demi kewajiban lantas selalu berarti bertindak berdasarkan maksim formal. Baru tindakan demikian bersifat baik secara moral. Selanjutnya dijelaskan bahwan bertindak berdasarkan maksim formal berarti bertindak berdasarkan prinsip yang murni dan a priori. "Murni" karena tidak memuat unsur-unsur emiris-material, dan "a priori" karena bersifat mutlak perlu dan tidak particular melainkan universal. Dengan kata lain dalam ajaran Kant, prinsip ini secara hakiki bersifat budiah, sebab hanya budi yang tidak memuat unsurunsur empiris-material, dan hanya budi yang bisa menjamin kemutlakan suatu kaidah. .(Tjahjadi, 1991: 53).

Moralitas adalah "kebaikan tertinggi" (summum bonum), dan kebaikan tertinggi tentunya juga berarti kebahagiaan sempurna (bukan kebahagiaan dalam arti empiris).
Selanjutnya Kant menyatakan bahwa moralitas mengarah kepada agaman melalui "pemahaman mengenai kebaikan tertinggi" (Begriff des hochsten Guts). Bahwa Allah adalah Yang Sempurna (kudus dan baik) secara moral. Maka kehendak dan perintahnNya adalah sempurna juga (kudus dan baik) secara moral. Mengingat bahwa tujuan moralitas adalah kebaikan tertinggi, sementara kebaikan tertinggi itu terdapat dalam Allah dan hanya bisa dicapai dengan menerima adanya Allah sebagai postulat, maka kalua kita mau mencapai tujuan itu, kita mesti menyelaraskan diri dengan kehendak dan perintah Allah yang sempurna secara moral tersebut. Dengan adanya penyelarasan inilah, kita mengakui kewajiban kita sebagai perintah Allah.(Tjahjadi, 1991: 57).

\section{Relevansi sila ke-3 Pancasila Buddhis dengan Filsafat Moral Immanuel Kant}

Dari aspek religious perbuatan perzinahan adalah perbuatan yang melanggar sila ke-3 dari Pancasila Buddhis yaitu: "Aku bertekad untuk melatih diri menghindari perbuatan perzinahan".

Hal yang mendasar dalam menentukan moralitas adalah "apa yang membuat manusia baik?". Pancasila Buddhis sebagai pedoman bagi umat Buddha dalam bersikap dan berbuat secara tekstual maupun kontekstual memiliki tujuan untuk membuat manusia menjadi baik. Khsusnya pada sila ke-3, bahwa umat Buddha harus memiliki tekad untuk menghindari perbuatan-perbuatan yang termasuk dalam kategori perzinahan.

Filsafat moral Immanuel Kant bersifat apriori, ditandai dengan adanya istilah "wajib", "kewajiban", "baik atau buruk", "benar" dan "salah". Yang selanjutnya etika apriori ini disebut sebagai metafisika kesusilaan (Metaphysik der Sitten). Secara tekstual "Aku bertekad untuk melatih diri menghindari perbuatan perzinahan", tidak ada kata atai istilah "wajib" untuk tidak melakukan perbuatan perzinahan. Adanya kata "melatih diri menghindari" seolah-olah hanya sebatas "jika bisa/jika dapat" untuk melatih diri menghindari/menahan diri dari perbuatan itu. Kemudian pertanyannya apakah Pancasila Buddhis tidak sepaham 
dengan prinsip apriori Immanuel Kant?, sebagai berikut.

Secara kontektual, dapat dijelaskan bahwa Pancasila Buddhis bagi umat Buddha merupakan suatu hal yang "wajib" untuk dilaksanakanan. Seseorang yang menyatakan masuk menjadi umat Buddha maka harus menyatakan suatu tekad perlindungan yaitu dengan melafalkan dengan penuh penghayatan paritta $\mathrm{Ti}$ Sarana (Tiga Perlindungan), tekad yang ke-dua adalah tekad untuk berlindung kepada Dhamma atau ajaran. Berlindung kepada Dhamma diartikan bahwa Dhamma/ajaran adalah pelindung, dimaksudkan apabila ajaran itu dijalankan maka kehidupan akan menjadi baik dan terhindar dari hal-hal yang buruk, inilah yang dimaksudkan "Dhamma sebagai pelindung". Sementara itu Pancasila Buddhis merupakan salah satu dari ajaran itu, yang tertuang di dalam Kitab .(Dighanikaya III. 235).

Selanjutnya dalam Kitab Anguttara Nikaya III, (A. III: 25), Buddha menjelaskan bahwa pengikut awam yang memiliki moralitas adalah ia yang tidak mengambil apa yang tidak diberikan, tidak melakukan perbuatan asusila, tidak berbicara tidak benar, tidak minum anggur, minuman keras dan semua yang bersifat meracuni yang menjadikan landasan kelalaian. Dapat diartikan bahwa Pancasila Buddhis adalah pedoman sila bagi umat Buddha yang wajib untuk dijalankan untuk menjaga kehidupan yang baik. Dengan demikian prinsip apriori filsafat moral Immanuel Kant dapat dipenuhi bahwa bagi umat Buddha yang benar-benar umat Buddha adalah wajib untuk tidak melakukan perbuatan perzinahan.

Selanjutnya ciri khas paham kewajiban Immanuel Kant adalah bahwa yang diharuskan itu selalu kehendak. Kehendak baik dipandang sebagai kehendak yang mengandung kebaikan pada dirinya sendiri (an sich). Immanuel Kant menyelaraskan antara moralitas dengan kehendak. Suatu tindakan moral dapat dinyatakan baik ataupun benar secara moral bila sejalan dengan kehendak baik dan kesesuaian dengan kewajiban seseorang. Secara tekstual "Aku bertekad untuk melatih diri menghindari perbuatan perzinahan", terdapat kata "Aku bertekad" dapat dijelaskan bahwa terdapat suatu kehendak yang kuat untuk menjalankan sila yaitu menghindari perbuatan perzinahan. Tekad adalah kehendak yang kuat untuk menghindari perbuatan perzinahan disini mendasari kewajiban untuk menjalankan sila tersebut. Maka terdapat keselarasan antara moral dengan adanya tekad untuk menjalankan kewajiban pada sila ke-3 Pancasila Buddhis.

Ajaran moral Immanuel Kant, memiliki prinsip secara hakiki bersifat budiah, sebab hanya budi yang tidak memuat unsur-unsur empiris-material, dan hanya budi yang bisa menjamin kemutlakan suatu kaidah. Berdasarkan maksim formal, bertindak berdasarkan prinsip yang murni dan a priori. "Murni" karena tidak memuat unsur-unsur emiris-material, dan "a priori" karena bersifat mutlak perlu dan tidak particular melainkan universal. Dalam sila Pancasila Buddhis memuat unsur tekad yang dapat diartikan sebagai wujud sifat tanpa pamrih dan tanpa syarat atau tendensi apapun dalam melaksanakan sila tersebut. Secara kontekstual adanya tekad yang mendasari pelaksanaan sila ke-3, bahwa umat Buddha melakukan atau melaksanakan sila ke-3 Pancasila Buddhis dengan begitu saja dilaksanakan dengan tekad yang kuat untuk malakukan kewajiban itu.

Moralitas adalah "kebaikan tertinggi" (summum bonum). Filsafat moral Immanuel Kant, bahwa moralitas mengarah kepada agama melalui "pemahaman mengenai kebaikan tertinggi" (Begriff des hochsten Guts). Bahwa Allah adalah Yang Sempurna (kudus dan baik) secara moral. Maka kehendak dan perintah-Nya adalah sempurna juga (kudus dan baik) secara moral. Dengan adanya penyelarasan inilah, kita mengakui kewajiban kita sebagai perintah Allah.

Bentuk penyelarasan dalam pelaksanaan sila ke-3 Pancasila Buddhis, dapat dijelaskan bahwa Pancasila Buddhis merupakan ajaran Ketuhanan yang disampaikan melalui Buddha Gotama, tertuang di dalam Kitab Dighanikaya III. 235. Terdapat suatu usaha dan tekad untuk menyelaraskan dengan Allah dengan menjalankan sila-sila dalam Pancasila Buddhis yang merupakan pedoman moral bagi umat Buddha. Untuk dapat selaras 
dengan Allah maka sikap dan perbuatan manusia juga harus selaras dengan sifat-sifat Allah. Dan manusia menyelaraskan sikap dan perilakunya dengan sifat-sifat Allah dengan menjalankan sila dan ajaran Dhamma sebagai suatu hal yang wajib (apriori). Sehingga kewajiban untuk melaksanakan sila adalah suatu bentuk pengakuan dan kepatuhan atas ajaran Allah.

Dari aspek religious perbuatan perzinahan adalah perbuatan yang melanggar sila ke-3 dari Pancasila Buddhis yaitu: "Aku bertekad untuk melatih diri menghindari perbuatan perzinahan".

Hal yang mendasar dalam menentukan moralitas adalah "apa yang membuat manusia baik?". Pancasila Buddhis sebagai pedoman bagi umat Buddha dalam bersikap dan berbuat secara tekstual maupun kontekstual memiliki tujuan untuk membuat manusia menjadi baik. Khsusnya pada sila ke-3, bahwa umat Buddha harus memiliki tekad untuk menghindari perbuatan-perbuatan yang termasuk dalam kategori perzinahan.

Filsafat moral Immanuel Kant bersifat apriori, ditandai dengan adanya istilah "wajib", "kewajiban", "baik atau buruk", "benar" dan "salah". Yang selanjutnya etika apriori ini disebut sebagai metafisika kesusilaan (Metaphysik der Sitten). Secara tekstual "Aku bertekad untuk melatih diri menghindari perbuatan perzinahan", tidak ada kata atai istilah "wajib" untuk tidak melakukan perbuatan perzinahan. Adanya kata "melatih diri menghindari" seolah-olah hanya sebatas "jika bisa/jika dapat" untuk melatih diri menghindari/menahan diri dari perbuatan itu. Kemudian pertanyannya apakah Pancasila Buddhis tidak sepaham dengan prinsip apriori Immanuel Kant?, sebagai berikut.

Secara kontektual, dapat dijelaskan bahwa Pancasila Buddhis bagi umat Buddha merupakan suatu hal yang "wajib" untuk dilaksanakanan. Seseorang yang menyatakan masuk menjadi umat Buddha maka harus menyatakan suatu tekad perlindungan yaitu dengan melafalkan dengan penuh penghayatan paritta $\mathrm{Ti}$ Sarana (Tiga Perlindungan), tekad yang ke-dua adalah tekad untuk berlindung kepada Dhamma atau ajaran. Berlindung kepada Dhamma diartikan bahwa Dhamma/ajaran adalah pelindung, dimaksudkan apabila ajaran itu dijalankan maka kehidupan akan menjadi baik dan terhindar dari hal-hal yang buruk, inilah yang dimaksudkan "Dhamma sebagai pelindung". Sementara itu Pancasila Buddhis merupakan salah satu dari ajaran itu, yang tertuang di dalam Kitab .(Dighanikaya III. 235).

Selanjutnya dalam Kitab Anguttara Nikaya III, (A. III: 25), Buddha menjelaskan bahwa pengikut awam yang memiliki moralitas adalah ia yang tidak mengambil apa yang tidak diberikan, tidak melakukan perbuatan asusila, tidak berbicara tidak benar, tidak minum anggur, minuman keras dan semua yang bersifat meracuni yang menjadikan landasan kelalaian. Dapat diartikan bahwa Pancasila Buddhis adalah pedoman sila bagi umat Buddha yang wajib untuk dijalankan untuk menjaga kehidupan yang baik. Dengan demikian prinsip apriori filsafat moral Immanuel Kant dapat dipenuhi bahwa bagi umat Buddha yang benar-benar umat Buddha adalah wajib untuk tidak melakukan perbuatan perzinahan.

Selanjutnya ciri khas paham kewajiban Immanuel Kant adalah bahwa yang diharuskan itu selalu kehendak. Kehendak baik dipandang sebagai kehendak yang mengandung kebaikan pada dirinya sendiri (an sich). Immanuel Kant menyelaraskan antara moralitas dengan kehendak. Suatu tindakan moral dapat dinyatakan baik ataupun benar secara moral bila sejalan dengan kehendak baik dan kesesuaian dengan kewajiban seseorang. Secara tekstual "Aku bertekad untuk melatih diri menghindari perbuatan perzinahan", terdapat kata "Aku bertekad" dapat dijelaskan bahwa terdapat suatu kehendak yang kuat untuk menjalankan sila yaitu menghindari perbuatan perzinahan. Tekad adalah kehendak yang kuat untuk menghindari perbuatan perzinahan disini mendasari kewajiban untuk menjalankan sila tersebut. Maka terdapat keselarasan antara moral dengan adanya tekad untuk menjalankan kewajiban pada sila ke-3 Pancasila Buddhis.

Ajaran moral Immanuel Kant, memiliki prinsip secara hakiki bersifat budiah, sebab hanya budi yang tidak memuat unsur-unsur empiris-material, dan hanya budi 
yang bisa menjamin kemutlakan suatu kaidah. Berdasarkan maksim formal, bertindak berdasarkan prinsip yang murni dan a priori. "Murni" karena tidak memuat unsur-unsur emiris-material, dan "a priori" karena bersifat mutlak perlu dan tidak particular melainkan universal. Dalam sila Pancasila Buddhis memuat unsur tekad yang dapat diartikan sebagai wujud sifat tanpa pamrih dan tanpa syarat atau tendensi apapun dalam melaksanakan sila tersebut. Secara kontekstual adanya tekad yang mendasari pelaksanaan sila ke-3, bahwa umat Buddha melakukan atau melaksanakan sila ke-3 Pancasila Buddhis dengan begitu saja dilaksanakan dengan tekad yang kuat untuk malakukan kewajiban itu.

Moralitas adalah "kebaikan tertinggi" (summum bonum). Filsafat moral Immanuel Kant, bahwa moralitas mengarah kepada agama melalui "pemahaman mengenai kebaikan tertinggi" (Begriff des hochsten Guts). Bahwa Allah adalah Yang Sempurna (kudus dan baik) secara moral. Maka kehendak dan perintah-Nya adalah sempurna juga (kudus dan baik) secara moral. Dengan adanya penyelarasan inilah, kita mengakui kewajiban kita sebagai perintah Allah.

Bentuk penyelarasan dalam pelaksanaan sila ke-3 Pancasila Buddhis, dapat dijelaskan bahwa Pancasila Buddhis merupakan ajaran Ketuhanan yang disampaikan melalui Buddha Gotama, tertuang di dalam Kitab Dighanikaya III. 235. Terdapat suatu usaha dan tekad untuk menyelaraskan dengan Allah dengan menjalankan sila-sila dalam Pancasila Buddhis yang merupakan pedoman moral bagi umat Buddha. Untuk dapat selaras dengan Allah maka sikap dan perbuatan manusia juga harus selaras dengan sifat-sifat Allah. Dan manusia menyelaraskan sikap dan perilakunya dengan sifat-sifat Allah dengan menjalankan sila dan ajaran Dhamma sebagai suatu hal yang wajib (apriori). Sehingga kewajiban untuk melaksanakan sila adalah suatu bentuk pengakuan dan kepatuhan atas ajaran Allah.

\section{KESIMPULAN}

Dari aspek religious perbuatan perzinahan dipandang dari peraturan umat perumah tangga adalah melanggar sila ke-3 dari Pancasila Buddhis yaitu: "Aku bertekad untuk melatih diri menghindari perbuatan perzinahan". Syarat suatu perbuatan disebut sebagai perzinahan adalah: 1) ada objek pelanggaran (perbuatannya); 2) si pelanggar (pelaku); 3) sarana fisik yang siap sebagai kondisi untuk pemuasan nafsu itu (pasangan dalam melakukan perbuatan itu); dan 4) tindakan itu) terpenuhi atau terlaksana. Perbuatan perzinahan disebabkan oleh adanya keterikatan pada objek (lobha) dan kebodohan batin (moha), dan dipengaruhi oleh bentuk pikiran buruk (Akusala-cetasika) yaitu Ahirika (tidak malu berbuat jahat), dan Anottappa (tidak takut akan akibat berbuat jahat). Sehingga akibat dari perbuatan perzinaahn adalah memiliki musuh, tidak disukai semua orang, adanya rasa takut, adanya kecenderungan untuk jenis kelamin perempuan atau jenis kelamin netral pada kehidupan berikutnya. Dan secara sebagian besar perbuatan perzinahan dapat mendorong seseorang terlahir di alam setan (Peta) dan raksana (Asurakaya) apabila dengan kekuatan Lobha yang memimpin, dan terlahir di alam binatang (Tiracchanayoni) dengan kekuatan Moha yang mendominasi.

Capaian filsafat moral Immanuel Kant, bahwa perbuatan perzinahan adalah perbuatan yang tidak bermoral karena perbuatan itu tidak membuat manusia menjadi baik tetapi sebaliknya membuat hidup manusia menjadi tidak baik. Sehingga hal itu harus diperangi dengan menjalankan aturan moralitas yang apriori atau wajib dilaksankan supaya kehidupan manusia menjadi baik. Pelaksanaan sila yang didasari oleh kehendak yang kuat yaitu tekad untuk kebaikan diri manusia itu sendiri (an sich). Sila dilaksanakan sebagai kewajiban dengan tanpa syarat dan tanpa pamrih, murni dan a priori, murni untuk kewajiban itu. Dan hal ini sebagai bentuk penyelarasan manusia dengan Allah, dengan melaksanakan moralitas yang dilandasi oleh tekad yang tanpa syarat sebagai sebuah kewajiban hidup.

\section{DAFTAR PUSTAKA}

1. Kitab Anguttara Nikaya II (A.II). Terjemahan dari: Numerical Discoueses 
of The Buddha_An Anthologi of Suttas from the Anguttara Nikaya. diterjemahkan oleh Nyanaponika Thera dan Bhikkhu Bodhi. diterbitkan oleh Vihara Bodhivamsa: Klaten (2002).

2. Kitab Anguttara Nikaya III (A.III). Terjemahan dari: Numerical Discoueses of The Buddha_ An Anthologi of Suttas from the Anguttara Nikaya. diterjemahkan oleh Nyanaponika Thera dan Bhikkhu Bodhi. diterbitkan oleh Vihara Bodhivamsa: Klaten (2003).

3. Kitab Dhammapada. Terjemahan dari: The Buddha's Path of Wisdom. diterjemahkan oleh YM. Phra Rajavaracariya (Win Wijano). diterbitkan oleh Bahussuta Society. 2011.

4. Kitab Digha Nikaya. Terjemahan dari: The long Discourses of the Buddha A Translation of the Digha Nikaya. By Maurice Walshe. DhammaCitta, (2009).

5. Kitab Khuddakapatha I. Terjemahan dari: The Minor Readings (Khuddakapatha). diterjemahkan oleh Bhikkhu Nanamoli. diterbitkan oleh Vihara Bodhivamsa: Klaten (2001).

6. Kitab The Dhammasangani Volume I. Translated by U Kyaw Khine. Departmen for the Promotion and Propagation of the Sasana, Myanmar: a jinavamsa/carol law publication. (2016).

7. Paritta Suci. Padesanayakan Jawa Tengah. (2017).

8. Ayub, Kornelius Dwi Winarso. 2020. Perbandingan Etika Immanuel Kant Dan Joseph Fletcher Serta Relevansinya Terhadap Positivisme Hukum Di Indonesia. Jurnal Hukum Magnum Opus Agustus 2020 Volume 3, Nomor 2.

9. Gusmian, Islah.2014. Filsafat Moral Immanuel Kant Suatu Tinjauan Paradigmatik. Al-A'raf Jurnal Pemikiran Islam dan Filsafat Diterbitkan oleh Jurusan Tafsi Hadis dan Akidah Filsafat IAIN Surakarta. Vol. XI, No. 2, Juli Desember 2014 ISSN: 1693-9867.

10. Hilman, Didi. 2014. Delik Perzinahan Ditinjau Dari Perspektif Hukum Islam. Yustisi-Vol. 1 No. 1-Oktober 2014.
11. Huriyah, Lilik. 2019. Menyoal Disertasi Halalkan Zina. Harian Jawa Pos pada Selasa, 3 September 2019. www. uinsby.ac.id.

12. Ismayawati, Any.2016. Konsistensi Pasal 284 KUHP Terhadap Undang-Undang Dasar Negara Republik Indonesia Tahun 1945. Legality, Vol.24, No.1, Maret 2016-Agustus 2016.

13. Kaharuddin. 2005. Abhidhammatthasangaha. Yenwreko Wahana Karya: Jakarta.

14. Panjika. 2004. Kamus Umum Buddha Dharma Pali-Sanskerta-Indonesia. Tri Sattva Buddhist Centre: Jakarta.

15. Pudja dan Sudharta. 2002. Manawa Dharmasastra Manu (Manu Dharmasastra). Jakarta : CV. Pelita Nursatama Lestari.

16. Sales, Fransiskus Lega.2014. Martabat Manusia Dalam Perspektif Filsafat Moral Immanuel Kant. Jurnal Pendidikan dan Kebudayaan Missio, Volume 7, Nomor 1, Januari 2014. unikastpaulus.ac.id.

17. Sugiyono, 2018. Memahami Penelitian Kualitatif. Alfabeta: Bandung.

18. Suseno, Frans Magnis. 1997. 13 Tokoh Etika. Yogyakarta: Kanisius.

19. Tjahjadi, Lili. 1991. Hukum Moral Ajaran Immanuel Kant Tentang Etika Dan Imperatif Kategoris. Kanisius: Yogyakarta 